\title{
Are important bird areas and special protected areas enough for conservation?: the case of Bonelli's eagle in a Mediterranean area
}

\author{
Pascual López-López • Clara García-Ripollés · \\ Álvaro Soutullo $\cdot$ Luis Cadahía $\cdot$ Vicente Urios
}

\begin{abstract}
The Bonelli's eagle (BE) is considered by the European Union as a high-priority species for conservation in the Valencian Community (East of Spain). However, in 2006 the European Union opened a legal procedure against the Spanish Kingdom, accused of lacking of an adequate network of special protected areas (SPAs) to preserve the BE in the region. Here we evaluate whether important bird areas (IBAs) and SPAs network is enough to preserve this species, on the basis of a thorough analysis of habitat preferences. A GAP analysis is performed to conduct a revision of current SPAs and BirdLife proposed IBAs. Our results suggest that the current network of SPAs becomes insufficient to protect the BE. The IBAs network, although improves the current network of SPAs, increasing the percentage of BE potential habitat included, also results inadequate. We propose a new SPAs network according to the potential suitable habitat for the species. Given the trade-off between financial investment and the conservation of biodiversity, we propose to maximize the surface of potential habitat included in the protected network minimizing the surface of the region that would be necessary to protect, thus avoiding an unnecessary expense and otherwise unrealistic results.
\end{abstract}

Keywords GAP analysis · GIS · Habitat selection · Hieraaetus fasciatus · Predictive models $\cdot$ Raptors $\cdot$ Spain

\footnotetext{
P. López-López ( $\square)$

"Cavanilles" Institute of Biodiversity and Evolutionary Biology, University of Valencia,

Polígono de la Coma s/n, Paterna, Valencia, 46980, Spain

e-mail: Pascual.Lopez@uv.es, lopez.pascual@gmail.com

P. López-López · Á. Soutullo · L. Cadahía · V. Urios

Estación Biológica Terra Natura (CIBIO - Fundación Terra Natura), Universidad de Alicante,

Apartado 99, Alicante, 03080, Spain

C. García-Ripollés

Plaza Jesús de Medinaceli 6-3ํ-14, Valencia, 46024, Spain
} 


\section{Introduction}

Conservation of biological diversity is one of the greatest challenges that humans need to face up, given our vast capacity of transformation of the environment. This entails a complex planning of what we would like to protect, and a long debate about whether conservation of species, areas or processes is available in the literature (Groom et al. 2006; Meffe and Ronald 1997; Primack 2000; Pullin 2004). As a result, numerous international and national agreements have been aroused. Two of the most important agreements concerning biodiversity conservation took place in Europe, one usually referred to as the Habitats Directive (92/43/EEC, available at http://ec.europa.eu/environment/nature/nature_conservation/eu_nature_legislation/habitats_directive/index_en.htm), and other usually referred to as the Birds Directive (79/409/EEC, available at http://ec.europa.eu/environment/nature/ nature_conservation/eu_nature_legislation/birds_directive/index_en.htm). The latter provides the protection, management and control of naturally occurring wild birds within the European Union. One of its key provisions is the establishment of an internationally coordinated network of protected areas as figures in Article 4. This article requires Member States to identify and classify the most suitable territories in size and number for rare or vulnerable species listed in Annex I. These sites are known throughout the Member States as special protection areas (SPAs). The Directive envisages that the classification of SPAs by all Member States will result in a European network of protected sites. This SPA network, together with special areas of conservation under the Habitats Directive, will become the 'Natura 2000 Network'. In the case of Spain, the organization BirdLife International, through the important bird area (IBA) program, proposed the network of places to be finally included in the Natura 2000 Network. The Spanish Ornithological Society (SEO in Spanish) as a BirdLife partner took the responsibility for the IBA program nationally and designed a total of 391 IBAs in Spain (Viada 1998) (available at http://www.seo.org/ ibas.cfm).

Our case-species, the Bonelli's eagle (BE) (Hieraaetus fasciatus), is listed in Annex I of the Birds Directive and Appendix II of the Bern and Bonn Conventions. Nowadays it is considered as endangered in Spain according to IUCN categories (Real 2004) and as least concern worldwide (BirdLife 2004b). The estimated population in Europe ranges from 920 to 1,100 breeding pairs (BirdLife 2004a) and the strongholds of the BE European population live in the Iberian Peninsula, with 733-768 breeding pairs (Del Moral 2006). The BE is considered by the European Union as a high-priority species for conservation in the Valencian Community, our study area, and one of the most (if not the most) determinant species on the design of the IBAs proposed by BirdLife International in this geographic area. In fact, the Valencian Community is the third region with the larger BE population, holding the $13 \%$ of the Spanish population (López-López et al., in press a).

Nevertheless, although considered a target species for the designation of Special Protected Areas (SPAs) in Spain and, specially, the Valencian Community, the European Union opened in 2006 a legal procedure against the Spanish Kingdom due to the insufficient designation of adequate SPAs for the species listed in Annex I in seven Autonomous Communities (SEO 2006a, b). One of them is the Valencian Community, accused of lacking of an adequate network of SPAs to preserve the BE.

Systematic conservation planning requires first the identification of what species are priorities for conservation (in the case of birds), and subsequently the identification of what places are the most representative to protect them. However, we do not start from zero and an existing network of SPAs is currently designated. Therefore, it is necessary to evaluate the degree to which the focus species is represented in the existing protected areas. This 
task is usually referred as GAP analysis and it attempts to detect voids by the identification of species/areas that need further protection. The first available literature about this topic began in the eighties with the first papers of Kirkpatrick (1983), Scott et al. (1987) and Burley (1988). Despite of the development of GAP analysis (Araujo 2004; De Klerk et al. 2004; Dietz and Czech 2005; Fjeldsa et al. 2004; Maiorano et al. 2006; Oldfield et al. 2004; Pressey 1994; Rodrigues et al. 2004, 1999; Scott et al. 1993, 2001; Yip et al. 2004) there is a lack of fine-grain studies focusing on gap analysis and the conservation of endangered raptors.

In this paper we evaluate whether IBAs and SPAs network is enough to preserve BE, an endangered raptor, in a Mediterranean area. On the basis of a thorough analysis of habitat preferences, we quantify what amount of potential habitat surface remains protected by current SPAs and planned IBAs. A GAP analysis is performed to conduct a revision of current SPAs and BirdLife proposed IBAs and, as a last resort, a proposal of new SPAs for a further inclusion in Natura 2000 network is also presented.

\section{Methods}

\section{Study area}

The study area comprises the Valencian Community (located in the east of the Iberian Peninsula) (Fig. 1), including 23,382 $\mathrm{Km}^{2} ; 40^{\circ} 47^{\prime} \mathrm{N}, 37^{\circ} 50^{\prime} \mathrm{S}, 1^{\circ} 31^{\prime} \mathrm{W}, 0^{\circ} 31^{\prime} \mathrm{E}$; 0-1839 m.a.s.1. The area is geomorphologically characterized as the confluence of three main mountain ranges: the Iberian System, oriented northwest-southeast; the east-northeast-orientated structures of the Catalánides, parallel to the coastline; and the southwest-northeast-orientated structures of the Baetic System. There are also several mountain ranges inland, coastal plains and a central plateau, resulting on a much folded peak line. Climatologically, it belongs to the Mediterranean area, with an annual mean temperature varying between 17 and $26^{\circ} \mathrm{C}$ from north toward south in the coastal area, and between 7 and $11^{\circ} \mathrm{C}$ from the inner highlands toward the coastal area. The annual mean precipitation varies from 250 to $900 \mathrm{~mm}$, with maximum values during the fall and minimum values in the summer (Encarta-online 2006). In terms of bioclimatology, the study area supports an assortment in vegetation types and ecosystems from sea level to mountainous areas, including littoral marshes, semi-desert areas, Mediterranean oak forests and pine forests.

The area includes 15 inland and three marine SPAs (SPAs) protected according to regional laws (available as digital shapefile at http://bdb.cth.gva.es). There are also 19 IBAs proposed by BirdLife International to be considered as Special Bird Protection Areas (Viada 1998) (Fig. 2).

Collection of data

We conducted systematic censuses to monitor BEs from 2000 to 2006. During the breeding season all known territories and potential breeding ones were visited. Observations were made with a $20-60 \times$ telescope during clear days and $300 \mathrm{~m}$ from nesting cliffs to avoid disturbance to eagles (Steenhof and Kochert 1982). A territory was considered occupied if we observed nests with green leaves, typical pair behavior, courtship, brood rearing activity or young (Newton 1979; Steenhof and Kochert 1982). A minimum of three visits was made to every reproductive territory to confirm the presence/absence of the pairs, the existence of new nests and the presence of hatched chicks. 


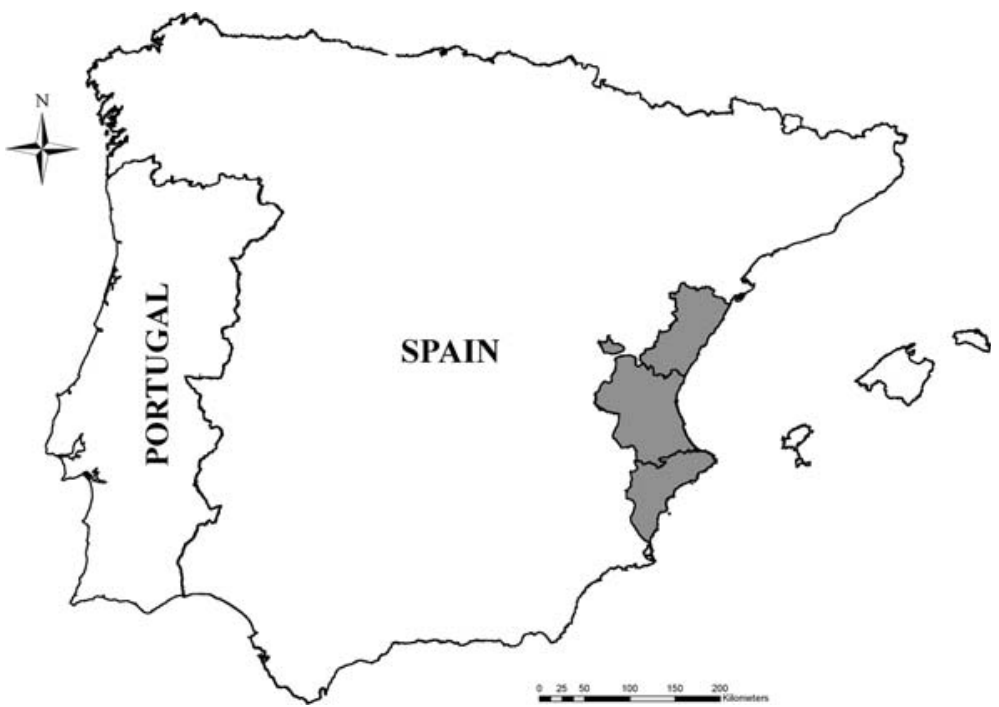

Fig. 1 Iberian Peninsula. The shaded region highlights the Valencia Community (the study area)

For the detection of dispersal areas, data from 15 juveniles tracked by satellite telemetry were employed. These individuals were trapped during the period 2002-2004, and tagged with a solar powered PTT-100 $(35 \mathrm{~g}, 17.4 \mathrm{~mm} \times 29.1 \mathrm{~mm} \times 62.5 \mathrm{~mm}$, antenna $17.8 \mathrm{~cm})$, manufactured by Microwave Telemetry Inc. (USA), which was fixed to the bird's body by a breakaway Teflon harness (Kenward 2001). The transmitters were set to an 8-h on/120-h off duty cycle and their weight represented $2.0 \%$ of the bird's body mass, well below the 3\% recommended by Kenward (2001). The management of the locations was made by downloading data from Argos system, a satellite-based location and data collection system [for an explanation on how the system works see Argos (1996) and Kenward (2001)]. Argos location classes 3, 2 and 1, with nominal accuracy $<150 \mathrm{~m}, 150-350 \mathrm{~m}$ and 350-1,000 m, respectively, were used in this study and implemented in a Geographic Information System software (Argos 1996), taking into account considerations made by Keating et al. (1991) and Soutullo et al. (in press).

\section{Predictive cartography}

Based on our prior experience in this topic with BE and other raptor species like Golden eagle Aquila chrysaetos (López-López et al., in press b), we used the best model obtained as a result of a complete study of BE breeding habitat preferences (López-López et al. 2006) to plot the potential habitat of the latter in the study area. A complete description of methods, variables considered and statistical methodology employed is available at LópezLópez et al. (2006). In short, a case-control design was used (Hosmer and Lemeshow 2000; Keating and Cherry 2004) corresponding to a sampling protocol C described

Fig. 2 Bonelli's eagle potential habitat in the study area. Only two probabilities of occurrence are depicted: medium (0.34-0.66) in pale grey and high (0.67-1.00) in dark grey. (a) Study area showing political subdivisions (provinces); (b) network of important bird areas according to BirdLife International; (c) current network of special protected areas (SPA); (d) proposed network of SPAs in this study 


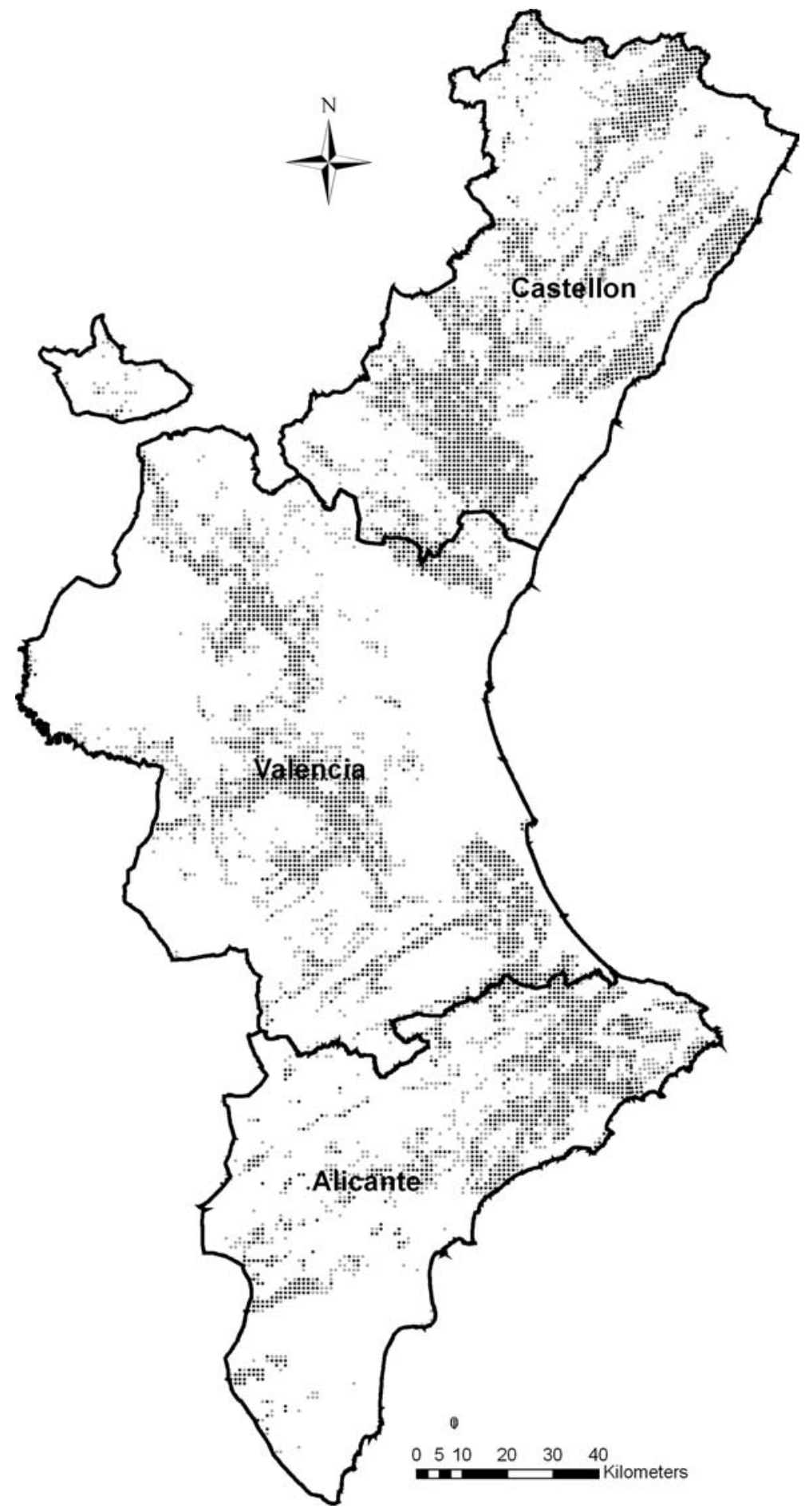




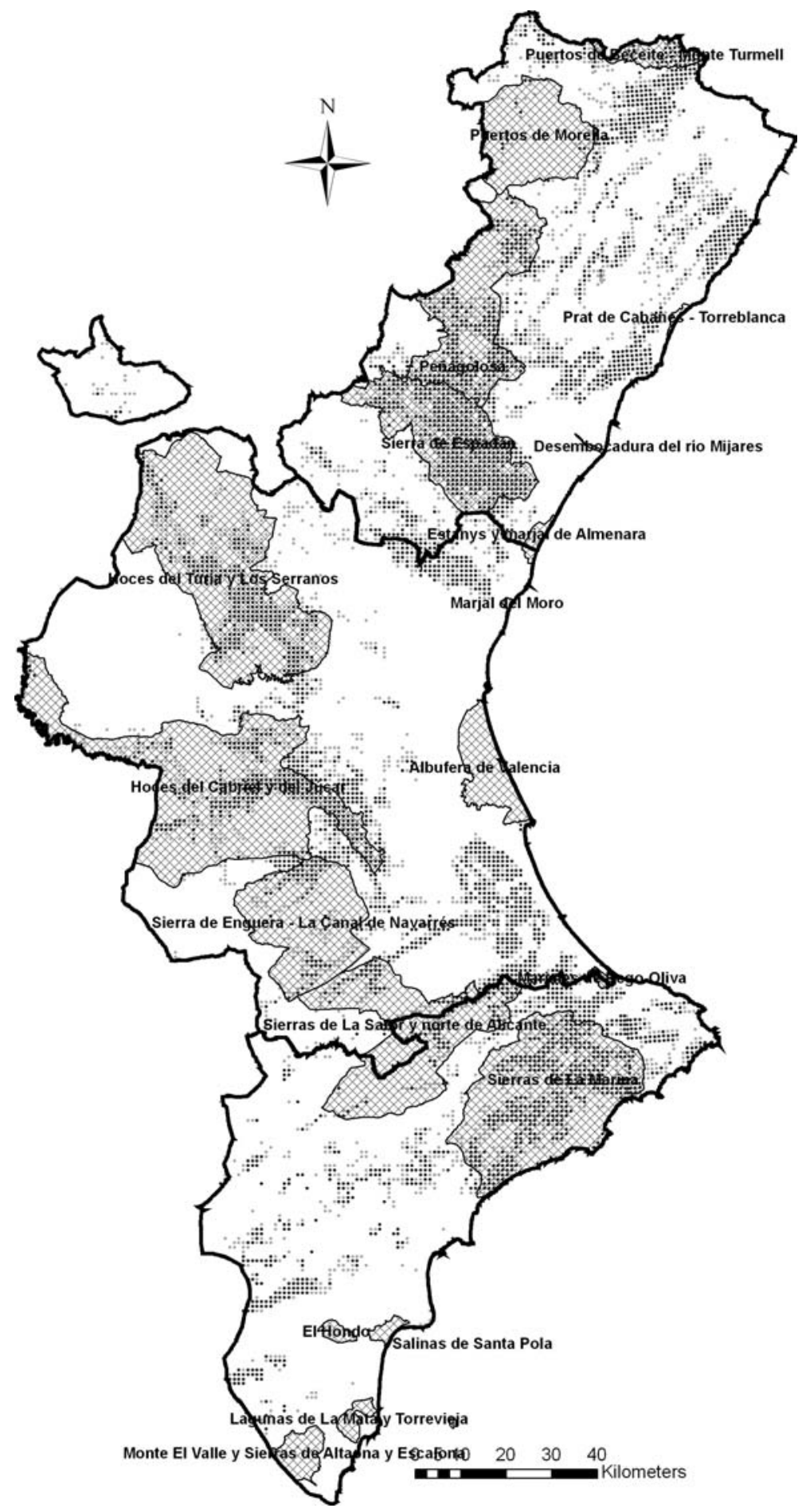

Fig. 2b continued 


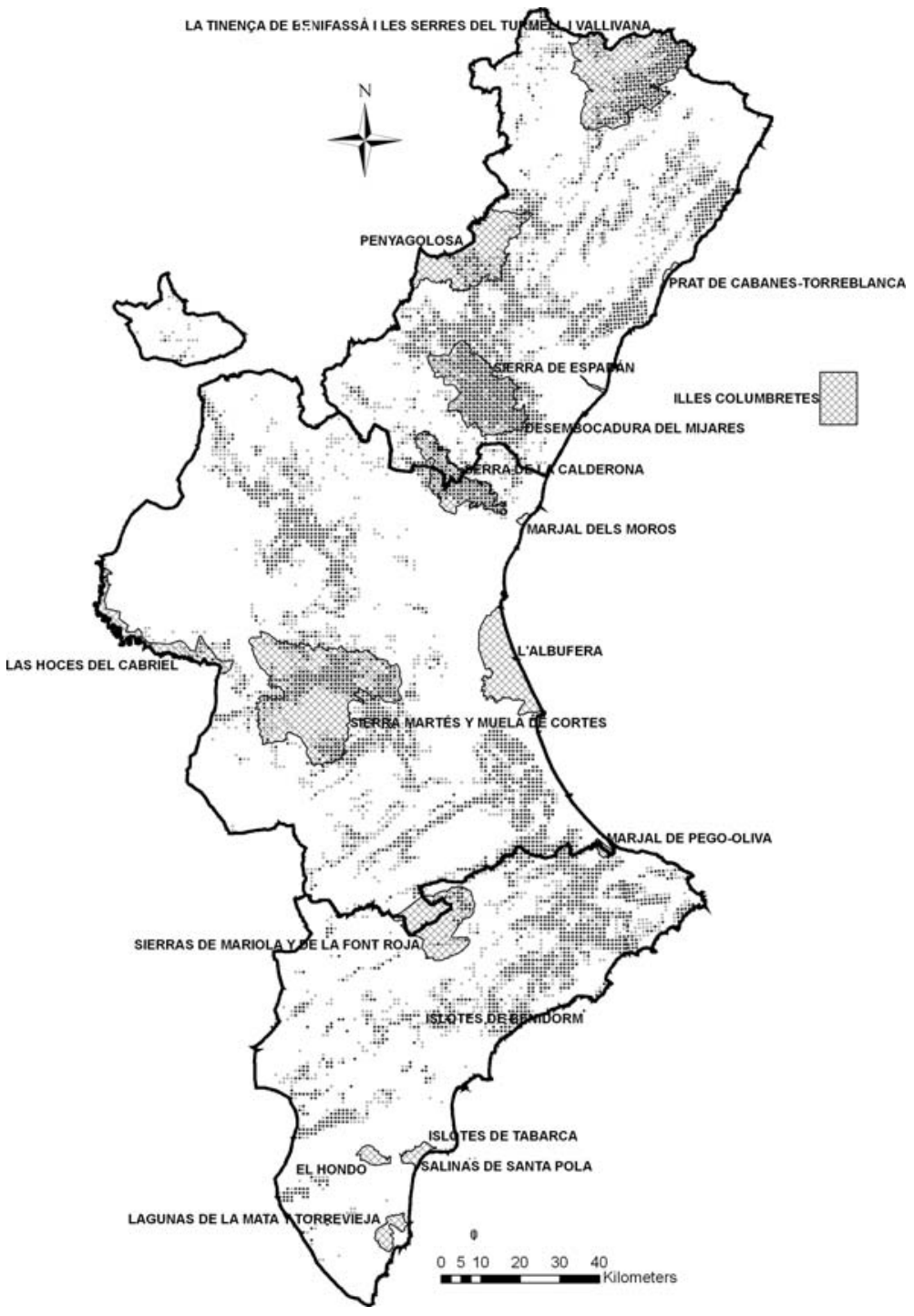

Fig. 2c continued

in Manly et al. (2002). A logistic regression using presence/absence of the species was used as dependant variable, and a set of topographic, climatic, land-use and disturbance factors were considered as independent predictors. They were included in the models by means of a stepwise selection procedure. The study was originally conducted using four concentric spatial scales: at $1 \mathrm{~km} \times 1 \mathrm{~km}, 3 \mathrm{~km} \times 3 \mathrm{~km}, 5 \mathrm{~km} \times 5 \mathrm{~km}$ and $9 \mathrm{~km} \times 9 \mathrm{~km}$ U.T.M. square plots with centre in the nest. However, in the present study we only use the best model obtained at $1 \times 1 \mathrm{~km}$ scale in order to increase spatial resolution. Models were generated with data of the northern province (Castellón) and validated with a set of independent data corresponding with the species occurrences in Valencia and Alicante 


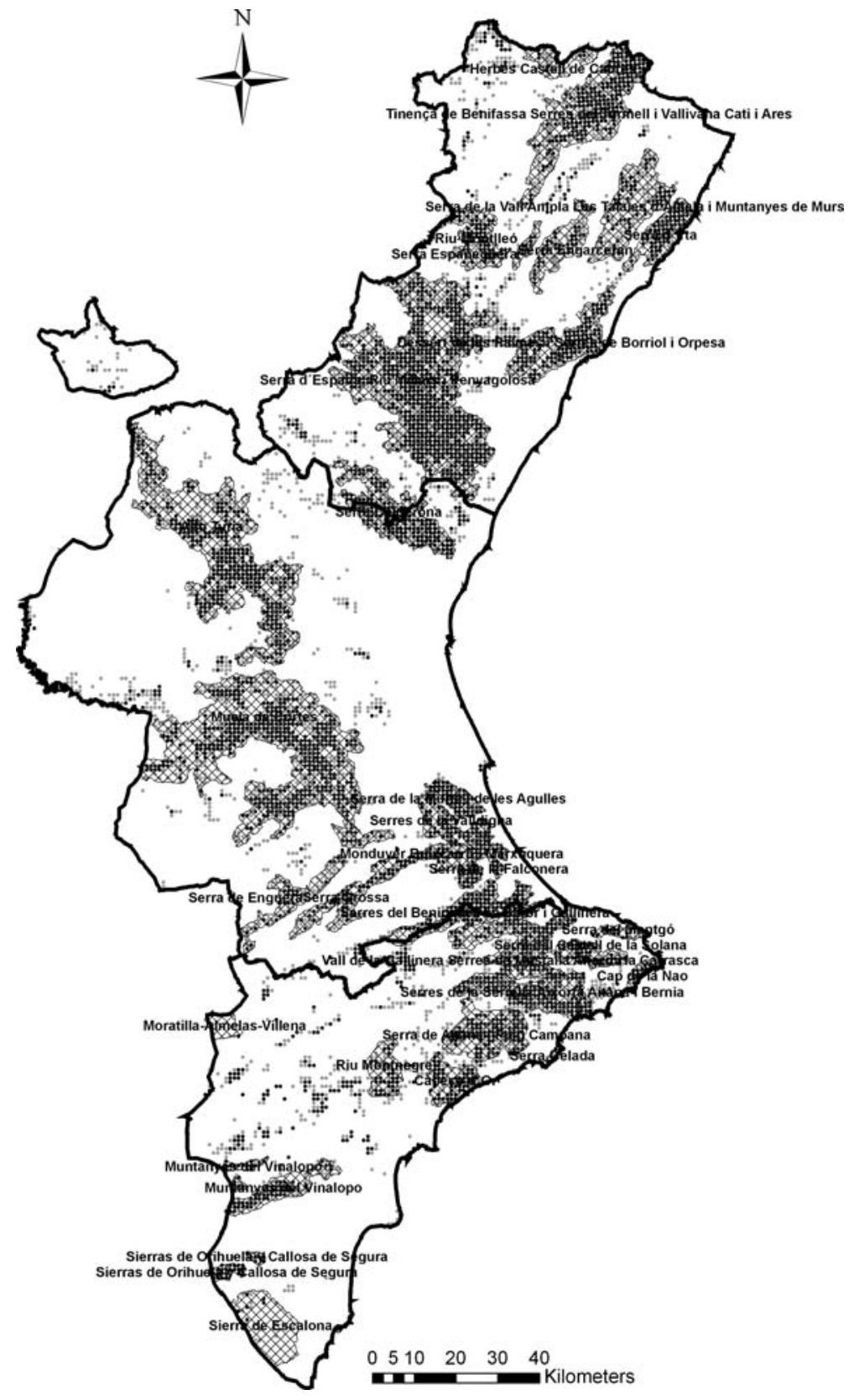

Fig. 2d continued

provinces, located southwards in the study area (Fig. 1). This validating procedure is recommended in the literature of predictive habitat distribution models (Pearce and Ferrier 2000) [for a complete review see Guisan and Zimmermann (2000)]. The spatial analysis was performed with ArcView GIS 3.2. (ESRI 1999). 
We distinguished three categories of habitat suitability: from 0 to 0.33 (low probability of BE occupancy), 0.34 to 0.66 (medium probability of BE occupancy) and 0.67 to 1.00 (high probability of BE occupancy). Once generated the predictive cartography, we identified and located the surface occupied by medium and high potential suitability areas. To do that, we represented graphically the BE potential habitat by means of a sequential removing procedure of $1 \%$ of the probability of occurrence beginning from 99 to $50 \%$ of probability of occurrence. These areas were grouped and delimited by polygons, trying to keep the major spatial cohesion as possible. The common requisite they should comply with was that the sum of the proportion of medium and high potential suitability habitat exceed $66 \%$ (i.e., there was much more medium and high suitability potential habitat than low suitability habitat). This new network was considered the proposed SPAs. In some cases, small areas (with an extension $<5 \mathrm{~km}^{2}$ ) with high proportion of potential habitat were not included given that the designation of very small protected areas lacks biological meaning for large raptors. Alternatively, some polygons included areas with low suitability potential habitat to keep the continuity of the polygons, but its proportion never exceed the $33 \%$ of the surface.

After that, a GAP analysis was performed by superimposition of digital shapes containing the BE potential habitat with the current SPAs, the IBAs and the proposed SPAs network, separately. First, we calculated the surface of each network and the percentage that they represent over the entire study area. Second, we calculated the surface of high suitability areas in the study area and the surface of this habitat category on current SPAs and IBAs. Third, we obtained the percentage of high suitability areas not included in SPAs and IBAs as a measure of their performance to preserve BE. Fourth, we calculated the overlap between the proposed SPAs and the IBAs networks. Furthermore, we calculated the surface of the IBAs network designated because of their importance on aquatic species (herons, waterfowls, waders, shorebirds and gulls) and consequently, the percentage over the entire study area they represent. Finally, we obtained the resulting surface of the proposed network of SPAs adding the surface of the IBAs designated by wetlands, and then, the percentage over the Valencian Community.

In all cases, we also calculated the potential habitat included in each SPAs, IBAs and proposed SPAs distinguishing the three categories of habitat suitability: low, medium and high probability of BE occupancy.

\section{Statistical analysis}

We compared the surface of low, medium and high suitability potential habitat within and between SPAs, IBAs and proposed SPAs separately, with a chi-square test (Sokal and Rohlf 1981). We also tested the differences in the proportion of high potential habitat among provinces in the study area, and the proportion of such potential habitat included within SPAs, IBAs and proposed SPAs, with the chi-square test. All computations were performed using STATISTICA version 7.0 for Windows (StatSoft 2004). Statistical significance was set at $P>0.05$.

\section{Results}

López-López et al. (2006) found that the best logistic regression model identified only topographic factors (altitude and slope) as the most parsimonious predictors of BE potential 
Table 1 Summary of Bonelli's eagle (BE) potential habitat included in special protected areas (SPAs), important bird areas (IBAs) and proposed special protected areas (SPAs proposed) per provinces of the study area

\begin{tabular}{rlrrrr}
\hline & & \multicolumn{1}{l}{ Low } & \multicolumn{1}{l}{ Medium } & Total \\
\hline \multirow{2}{*}{ Castellón } & SPAs & $431(35.98)$ & $257(21.45)$ & $510(42.57)$ & 1,198 \\
& IBAs & $881(47.37)$ & $311(16.72)$ & $668(35.91)$ & 1,860 \\
& SPAs proposed & $481(18.62)$ & $777(30.08)$ & $1,325(51.30)$ & 2,583 \\
& Province & $4,190(61.98)$ & $1,130(16.72)$ & $1,440(21.30)$ & 6,760 \\
Valencia & SPAs & $744(59.42)$ & $179(14.30)$ & $329(26.28)$ & 1,252 \\
& IBAs & $2,497(66.29)$ & $598(15.87)$ & $672(17.84)$ & 3,767 \\
& SPAs proposed & $667(24.15)$ & $809(29.29)$ & $1,286(46.56)$ & 2,762 \\
& Province & $8,228(76.34)$ & $1,213(11.25)$ & $1,337(12.40)$ & 10,778 \\
& SPAs & $216(80.60)$ & $28(10.45)$ & $24(8.96)$ & 268 \\
& IBAs & $946(55.68)$ & $293(17.25)$ & $460(27.07)$ & 1,699 \\
& SPAs proposed & $420(28.53)$ & $310(21.06)$ & $742(50.41)$ & 1,472 \\
& Province & $4,205(71.95)$ & $713(12.20)$ & $926(15.85)$ & 5,844 \\
& SPAs & $1,391(51.18)$ & $464(17.07)$ & $863(31.75)$ & 2,718 \\
& IBAs & $4,324(59.02)$ & $1,202(16.41)$ & $1,800(24.57)$ & 7,326 \\
& SPAs proposed & $1,568(23.00)$ & $1,896(27.81)$ & $3,353(49.19)$ & 6,817 \\
& Valencian Community & $16,623(71.09)$ & $3,056(13.07)$ & $3,703(15.84)$ & 23,382 \\
\hline
\end{tabular}

Three categories of habitat suitability are shown: low probability of BE occupancy (0-0.33), medium (0.34$0.66)$ and high $(0.67-1.00)$. Units are expressed in $\mathrm{km}^{2}$. The percentage of each category over the total is shown in brackets

habitat for nesting. They found that the probability of occurrence of BE decreases with the altitude, but is increased by the slope of the square. The inclusion of climatic, disturbance and land use variables did not improve the predictive power of the model. With this model, the BE potential habitat, taking into account only high probability of occurrence $(>0.67)$, extends $3,703 \mathrm{~km}^{2}$ over the study area covering $15.84 \%$ of the total surface. A complete summary of BE potential habitat included in SPAs, IBAs and proposed SPAs is shown in Table 1.

The GAP analysis indicates that the current network of SPAs only protects a few percentage of the BE potential habitat (Table 2). Moreover, the IBAs improves the current network of SPAs, increasing the percentage of BE potential habitat included. However, there is a $26 \%$ of the high suitability areas not included in the IBAs (Table 2).

We have identified 33 polygons that constitute the proposed network of IBAs. Eleven are located in the Castellón province, nine in Valencia and eleven in Alicante. In addition, one is shared between Castellón and Valencia, and one more between Valencia and Alicante (Table 5). Furthermore, two areas have been proposed because they are dispersal areas of juveniles, both in the Alicante province (Moratilla-Almelas-Villena and Sierra de Escalona). In these areas, locations of at least three juveniles during the period 2002-2006 were reported by satellite telemetry (Fig. 3). Only in these areas the proportion of low suitability area exceeds the $33 \%$ of the surface of the polygon, given that it is based on potential suitability for nesting.

The potential habitat included in the network of IBAs extends $1,800 \mathrm{~km}^{2}$ (or $48.61 \%$ of the entire potential habitat) (Fig. 2b; Table 4), whereas the current network of SPAs includes only $863 \mathrm{~km}^{2}$ of the potential habitat (or $23.31 \%$ of the entire potential habitat) (Fig. 2c; Table 3). The proposed network of SPAs includes $3,353 \mathrm{~km}^{2}(90.55 \%$ of the entire potential habitat) (Fig. 2d; Table 5). We found differences in the surface of low, 
Table 2 GAP analysis of the performance of the current network of special protected areas (SPAs) and important bird areas (IBAs) of the Valencian Community

\begin{tabular}{lr} 
Surface of the current SPA network & 2,718 \\
\hline
\end{tabular}

Total surface of the study area (Valencian Community)

23,382

Percentage of the study area occupied by the current network of SPAs

$11.62 \%$

Surface of high suitability areas (probability of occurrence $>67 \%$ ) in the study area $\quad 3,703$

Surface of high suitability areas included in the current SPAs network

863

Percentage of high suitability areas not included in the current SPAs network

$76.69 \%$

Surface of the proposed network of SPAs

6,817

Percentage of the study area occupied by the proposed network of SPAs

$29.15 \%$

Surface of the IBAs network

7,326

Percentage of the study area occupied by the IBAs network

$31.33 \%$

Surface of IBAs network designated by wetlands

Percentage of the study area of the IBAs network designated by wetlands ${ }^{a}$

354

$1.51 \%$

1,800

Surface of high suitability areas included in the IBAs network
Percentage of high suitability areas not included in the IBAs network

$25.98 \%$

Surface of the proposed SPAs network included in the IBAs network

Surface of the proposed SPAs network not included in the IBAs network

3,370

Percentage of the proposed network of SPAs not included in the IBAs network

$49.44 \%$

Surface of the proposed network of SPAs adding the surface of IBAs designated by wetlands

7,171

Percentage of the Valencian Community that would be protected including

$30.67 \%$

the proposed SPAs network and IBAs designated by wetlands

See text for further details. Surface units are expressed in $\mathrm{km}^{2}$

a These IBAs are: Desembocadura del Riu Millars. Estanys and marjal de Almenara, Prat de Cabanes-Torreblanca, Albufera de Valencia, Marjal del Moro, Marjales de Pego-Oliva, Lagunas de la Mata and Torrevieja, El Hondo, Salinas de Santa Pola

medium and high suitability potential habitat within SPAs $\left(\chi^{2}=477.30 ; d f=2\right.$; $p<0.001)$, IBAs $\left(\chi^{2}=2,248.85 ; d f=2 ; p<0.001\right)$ and proposed SPAs $\left(\chi^{2}=794.58\right.$; $d f=2 ; p<0.001$ ) (Table 1). Moreover, there were also differences in the surface of the three types of habitat between SPA, IBAs and proposed SPAs $\left(\chi^{2}=1,964.90 ; d f=4\right.$; $p<0.0001)$. A detailed description of the surface of low, medium and high suitability habitat included in each SPA, IBA and proposed SPA is shown in Tables 3, 4, and Table 5, respectively.

There were no differences in the proportion of high potential habitat among provinces in the study area $\left(\chi^{2}=2.43 ; d f=2 ; p<0.295\right)$. However, there were differences in the proportion of such potential habitat included in SPAs $\left(\chi^{2}=7.09 ; d f=2 ; p<0.029\right)$, but not in IBAs $\left(\chi^{2}=0.84 ; d f=2 ; p<0.658\right)$ nor in proposed SPAs $\left(\chi^{2}=2.42 ; d f=2\right.$, $p<0.298$ ).

When performing a sequential removing procedure of $1 \%$ of the probability of occurrence of $\mathrm{BE}$, we found a non-linear relationship between this variable and the surface that would be necessary to protect to include all cells with a probability of occurrence higher than a certain value (Fig. 4). The curve fits to an exponential decay with the following expression: $y=a \times \exp (-b \times x)$; where $y=$ total surface, $a=18,246.96 \quad(t=29.05$; $p<0.0001), b=2.60(t=27.51 ; p<0.0001), x=$ probability of BE occurrence, and an overall adjusted $r^{2}=0.97$. With the sequential removal of one unit in the probability of occurrence of the species and intending to reach the same percentage of protected surface that the proposed IBAs network (i.e., $31.33 \%$ of the study area), it would be necessary to include cells with a probability of occurrence higher than or equal to 0.25 (the cut-off point) (Fig. 5). 


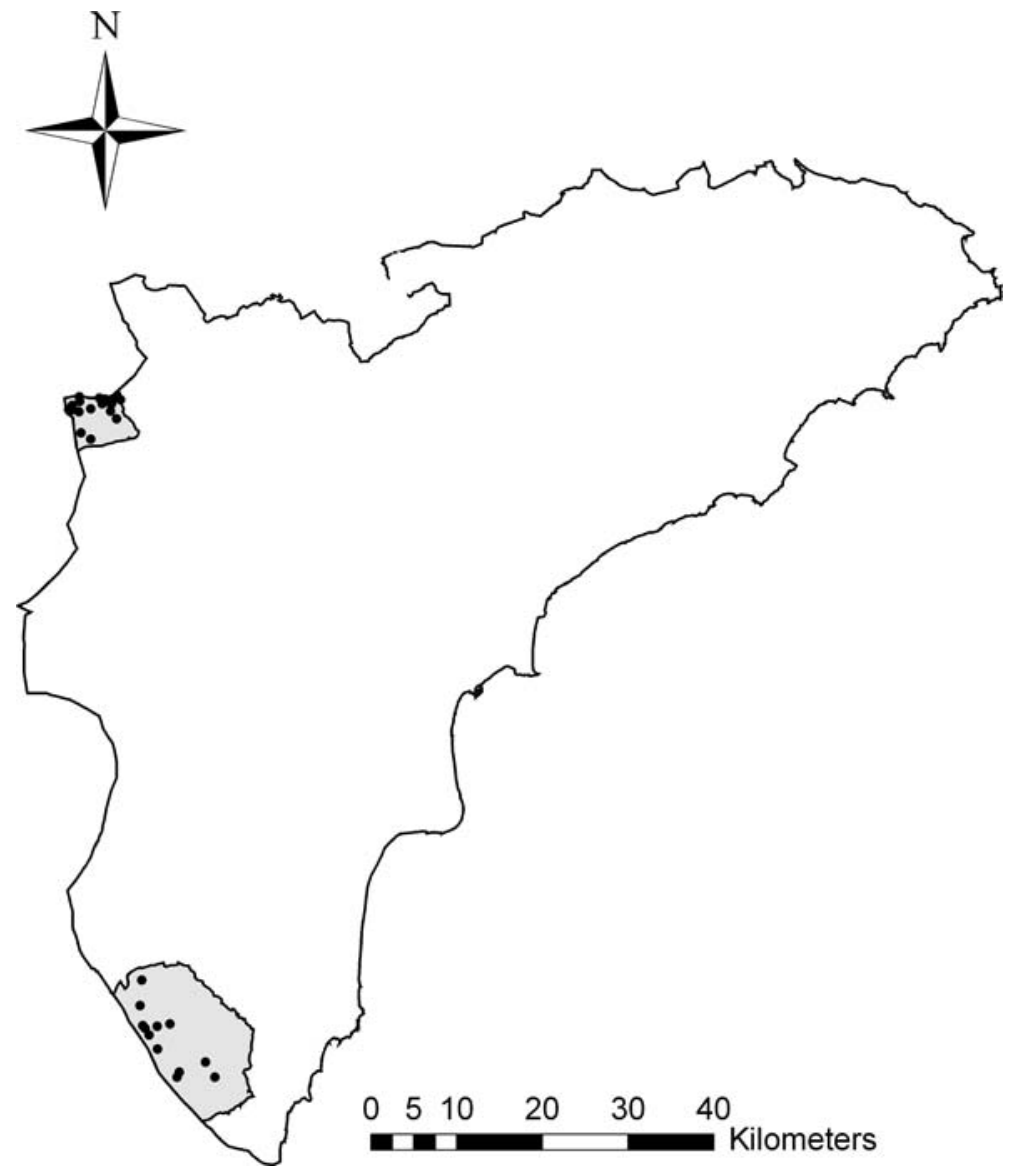

Fig. 3 Locations of three Bonelli's eagle juveniles during their dispersal period in the study area. The proposed important bird areas are marked in grey

\section{Discussion}

Applied research directed at bird conservation usually attempts to improve understanding of habitat preferences and the relationship between population demography and habitat quality (Sutherland and Green 2004). In this sense, thorough studies aimed at quantifying habitat quality could be useful to enhance conservation efforts. Reserve design should not consider only the current occupied habitat of a species, but also should take into account the potential suitable habitat for it.

Although a criticized strategy (Andelman and Fagan 2000; Kerr 1997), top-predators like raptors and charismatic vertebrates have been used for protected areas planning (Carroll et al. 2001; Murphy and Noon 1992) and recently, tested as adequate surrogates for conservation (Sergio et al. 2005, 2006). In this paper we propose to design protected areas, previously determining the potential habitat of the target species based on a previous GIS-based habitat selection analysis and, after that, evaluating how effective is the current 


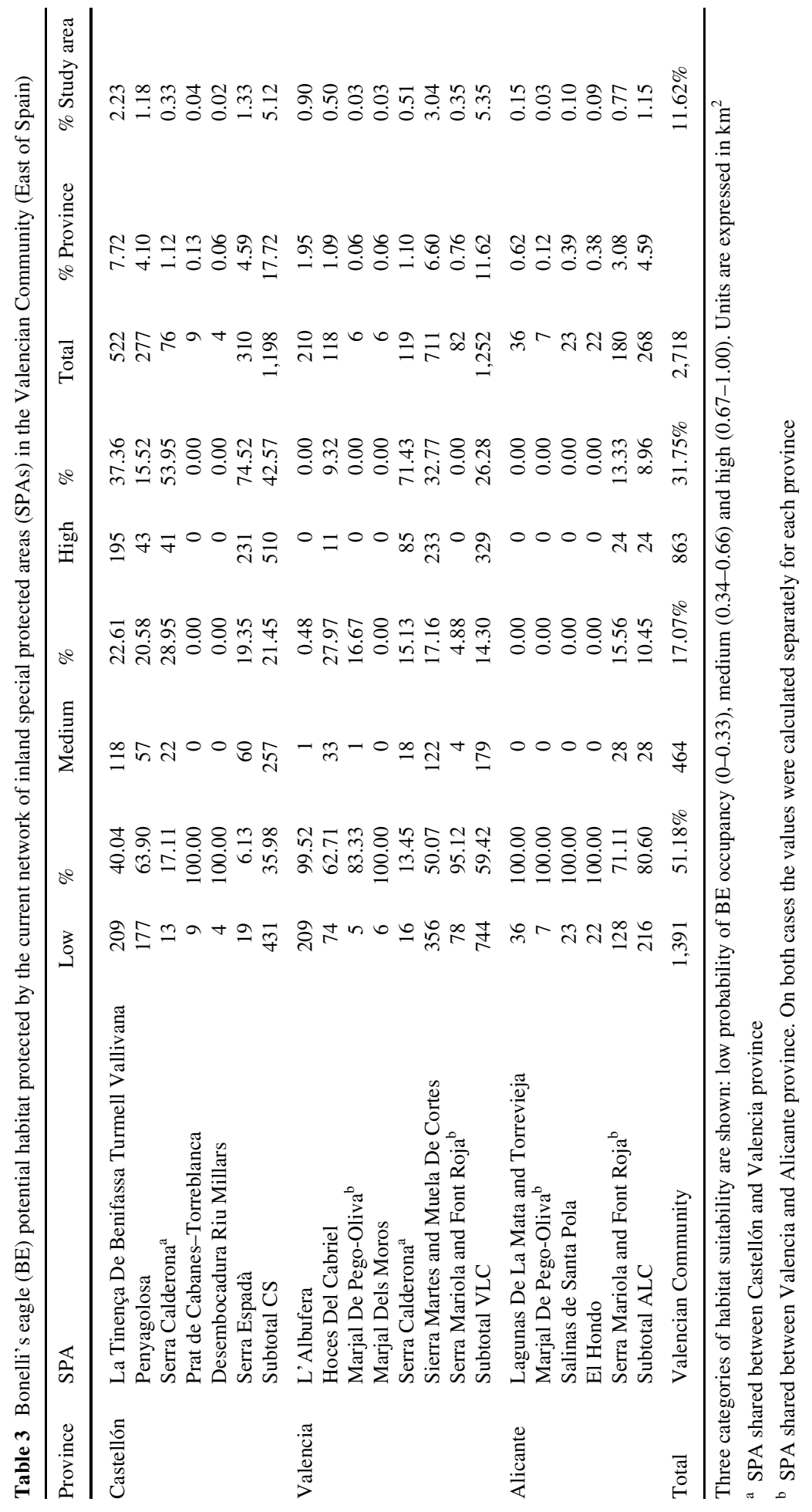




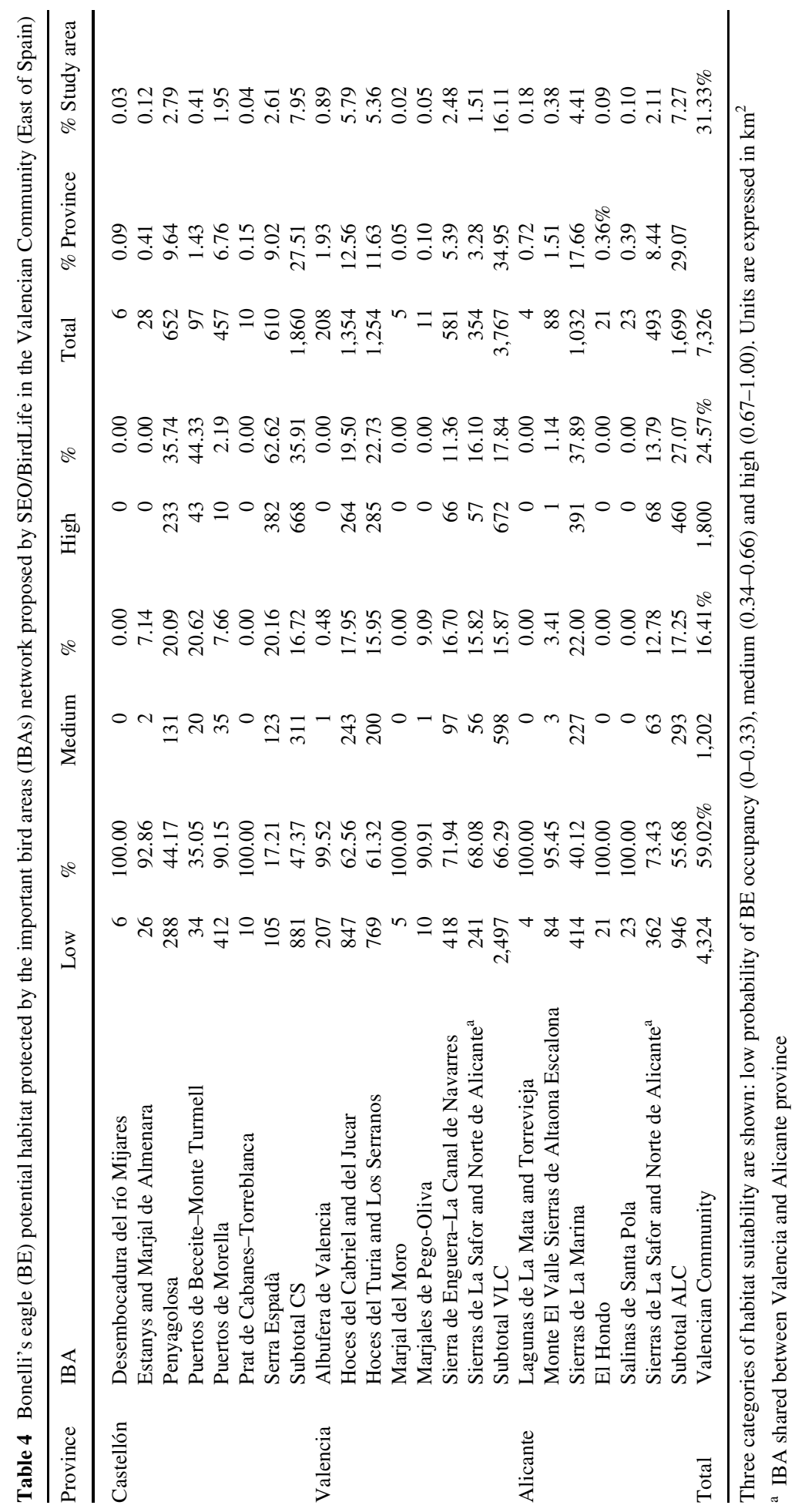




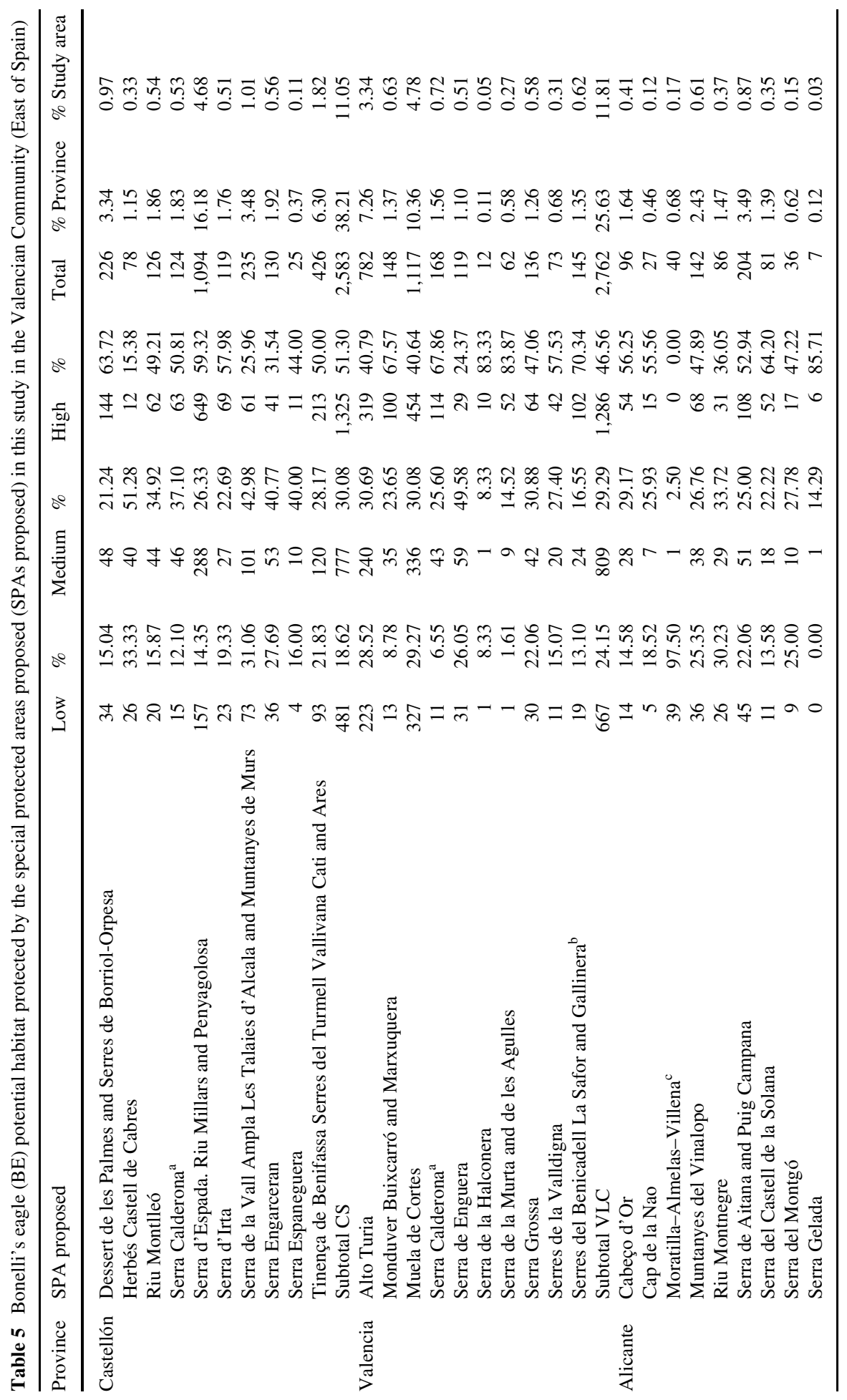




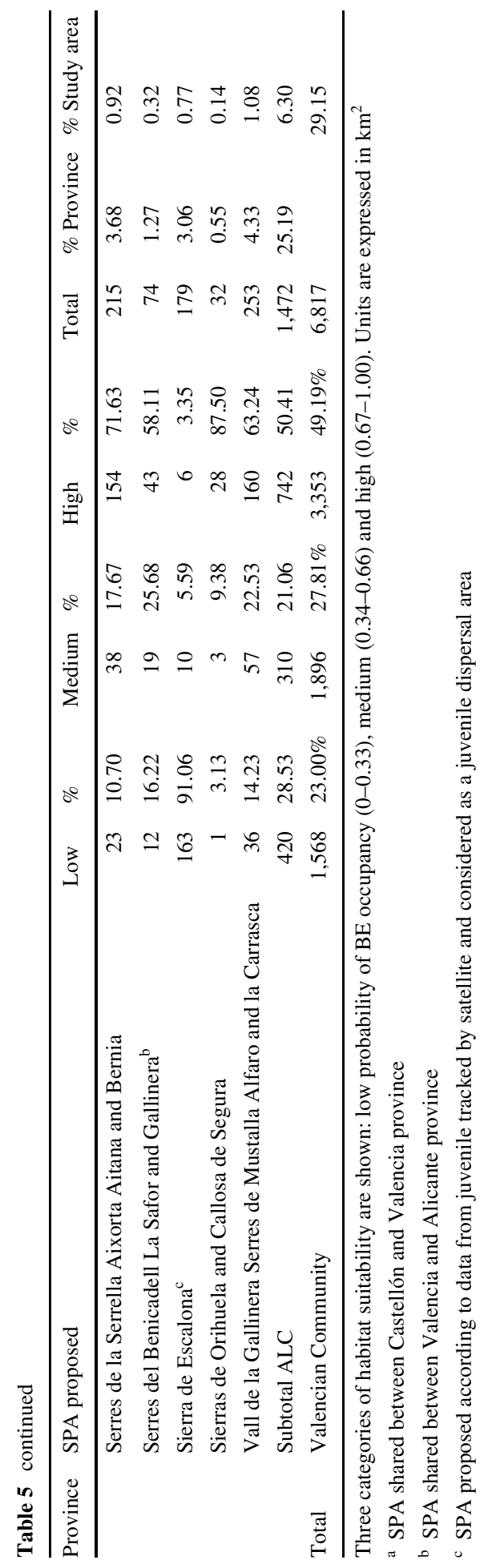




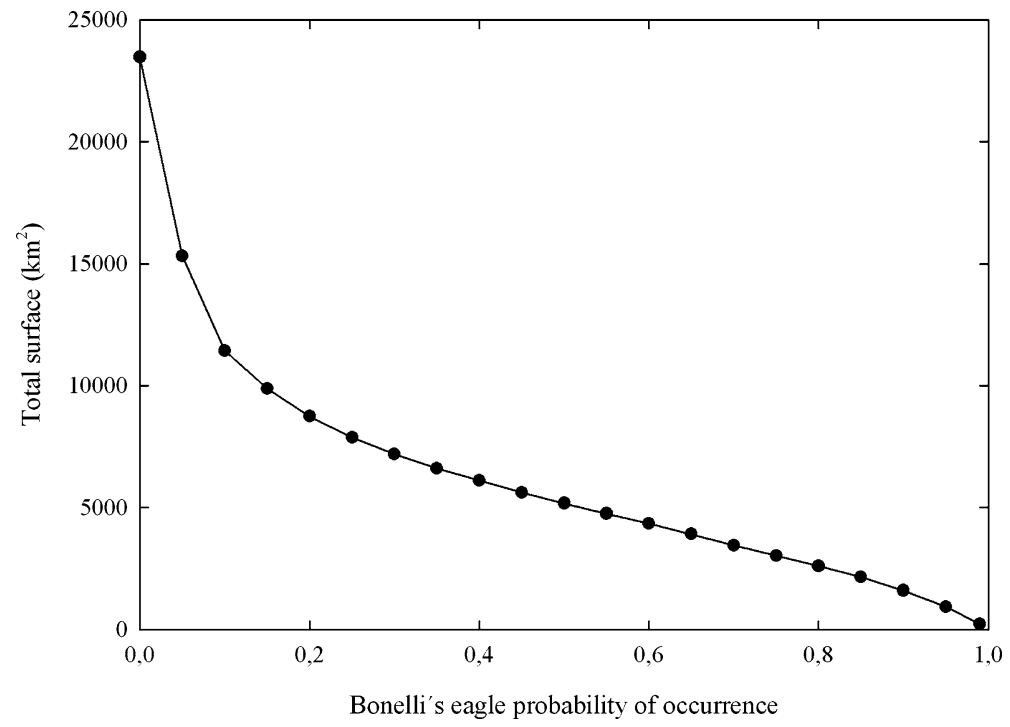

Fig. 4 Surface of the study area that would be necessary to protect in relation to the probability of occurrence of the Bonelli's eagle

network of SPAs in relation to the protection of high potential habitat for the species (the GAP analysis). Then, after securing the results of this evaluation, we propose to quantify how much should the SPAs network need to be extended to include a significant proportion of high suitable habitat. This analysis provides an indication of the need for redesign of SPAs network if they would like to protect effectively the target species. A similar analysis was also performed with the proposal of IBAs of SEO/BirdLife.

Overall, our results suggest that the current network of SPAs becomes insufficient to protect the $\mathrm{BE}$, even though the species is considered as a top priority for conservation in the Valencian Community, according to the European Union. Nevertheless, the lacking of protected areas becomes different in relation to the province in which the study area is divided, increasing in a gradient of ineffectiveness from north to south. We have found that the network of IBAs proposed by SEO/BirdLife improves the current network of SPAs, increasing the percentage of BE potential habitat included. However, to increase the percentage of BE potential habitat included in protected areas, maintaining the total surface purposed by the IBA network (it means approximately a $30 \%$ of the entire study area), it would be necessary a redesign of the current SPAs.

According to the potential suitability map we propose a new SPAs network, starting from the existing SPA protected network and taking into account the proposed network of IBAs of SEO/BirdLife. This network is divided in inland IBAs (those focused on protecting BE and other raptors like Golden eagle or Eurasian eagle-owl Bubo bubo) and wetland IBAs (those focused on wetland species of the littoral marshes). Our proposal allows to increase the percentage of BE potential habitat included in protected areas, trying not to exceed the total surface proposed by the network of inland IBAs. On the other hand,

Fig. 5 Predictive cartography of Bonelli's eagle potential habitat. Probability of occurrence is shown by means of a sequential removing procedure from (a) 95\% probability of occurrence; (b) 90\%; (c) 80\%; (d) $70 \% ;($ e) $60 \% ;$ (f) $50 \%$ 


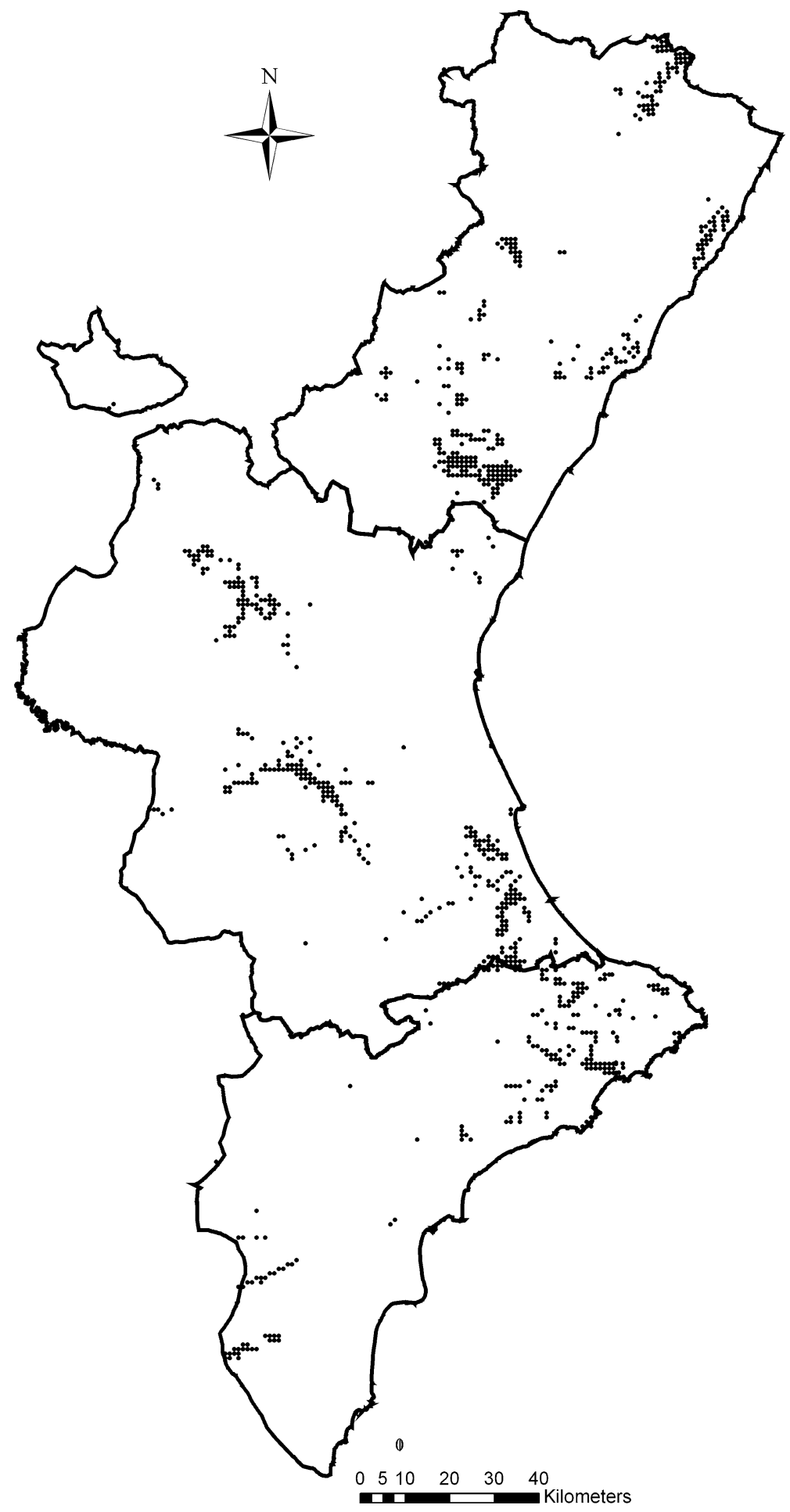




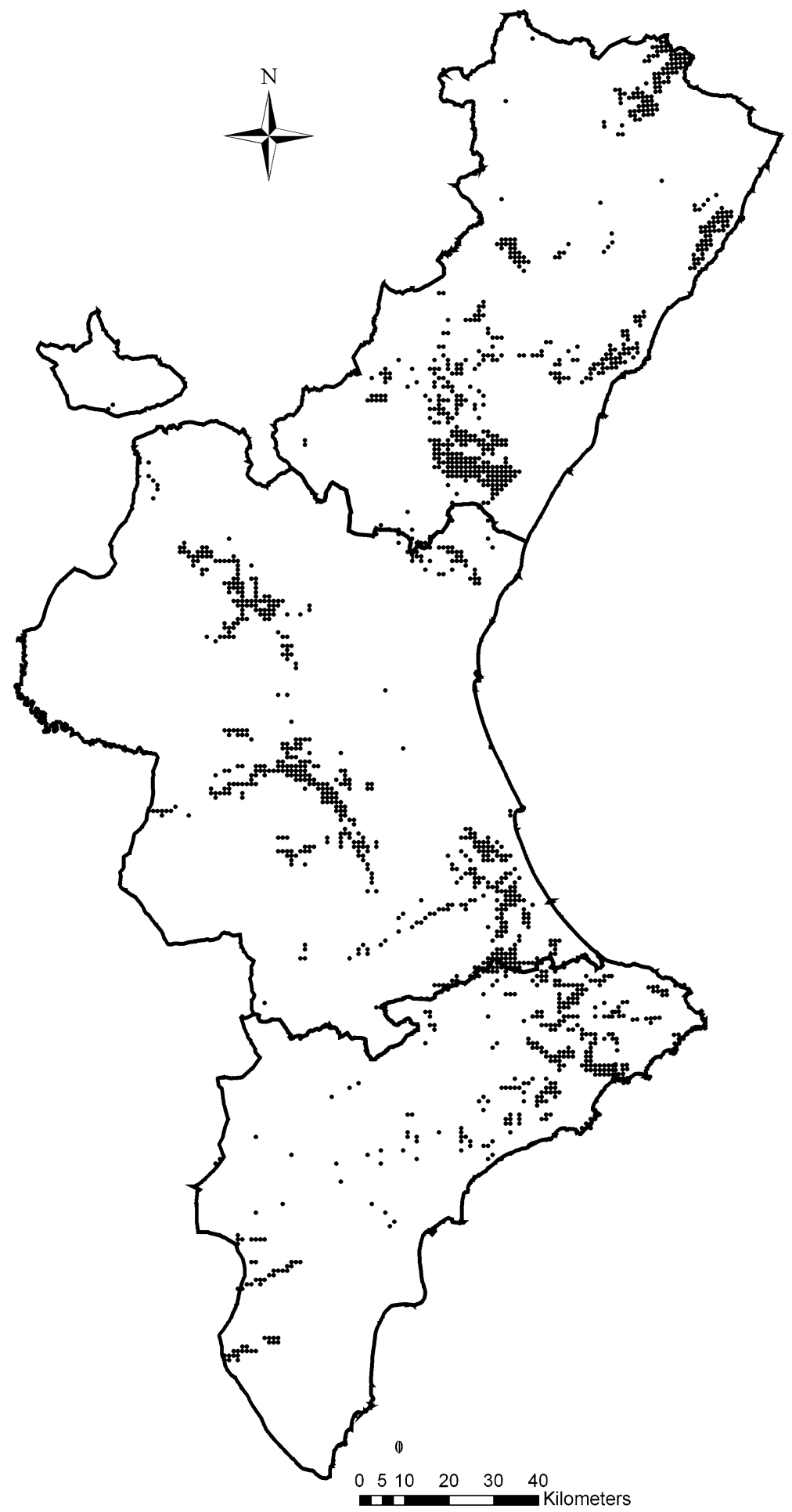

Fig. 5b continued 


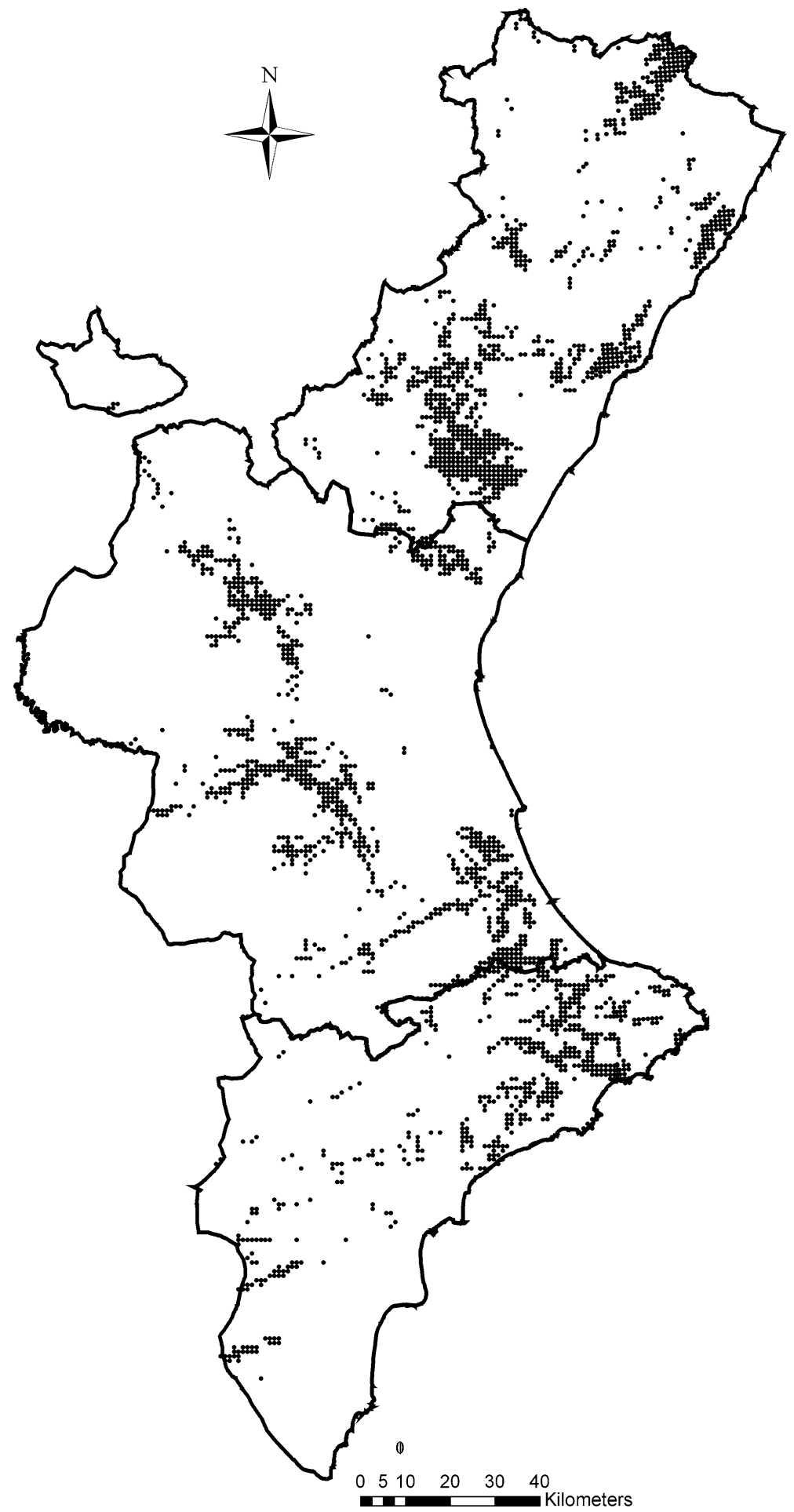

Fig. 5c continued 


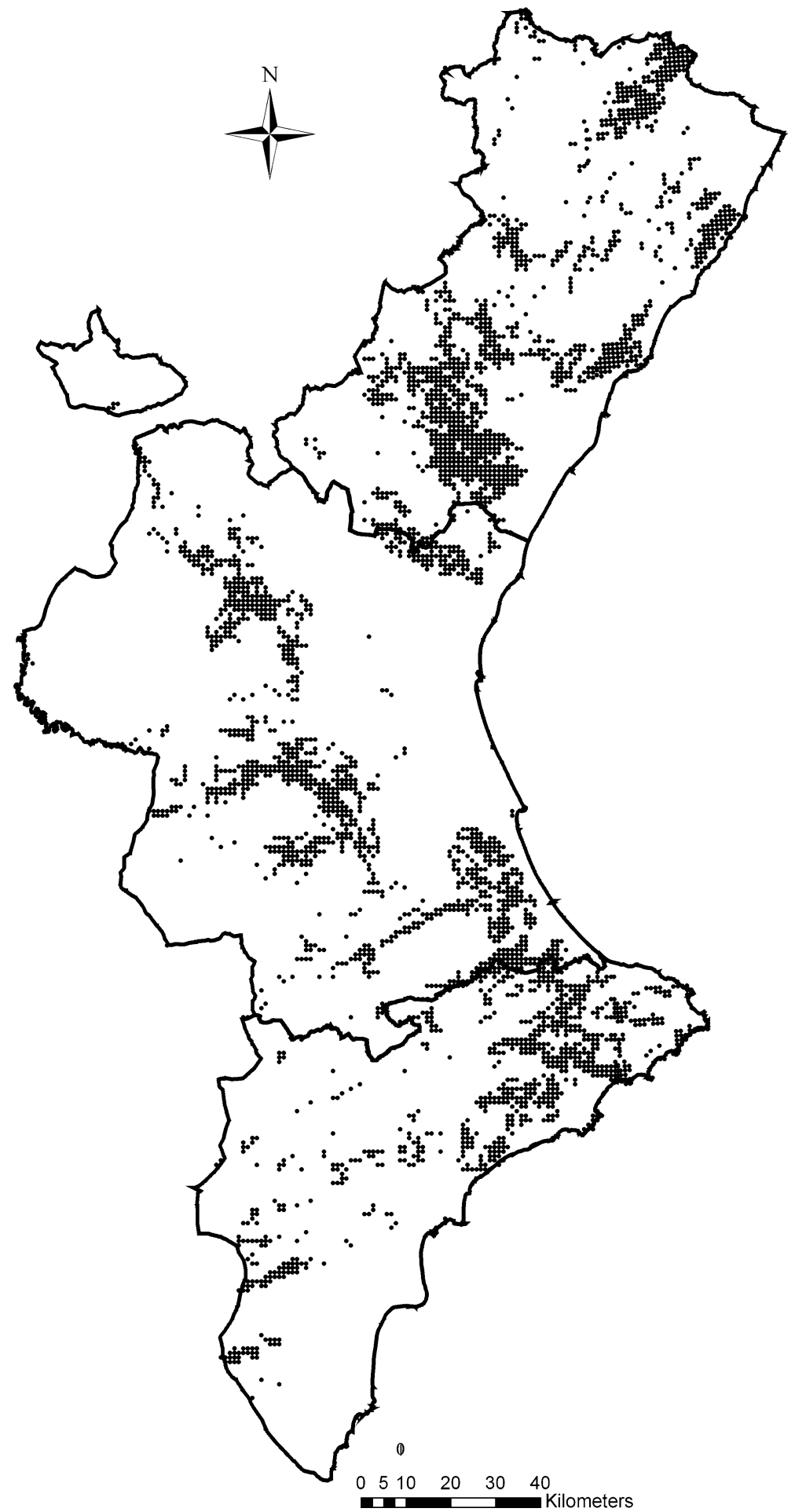

Fig. 5d continued 


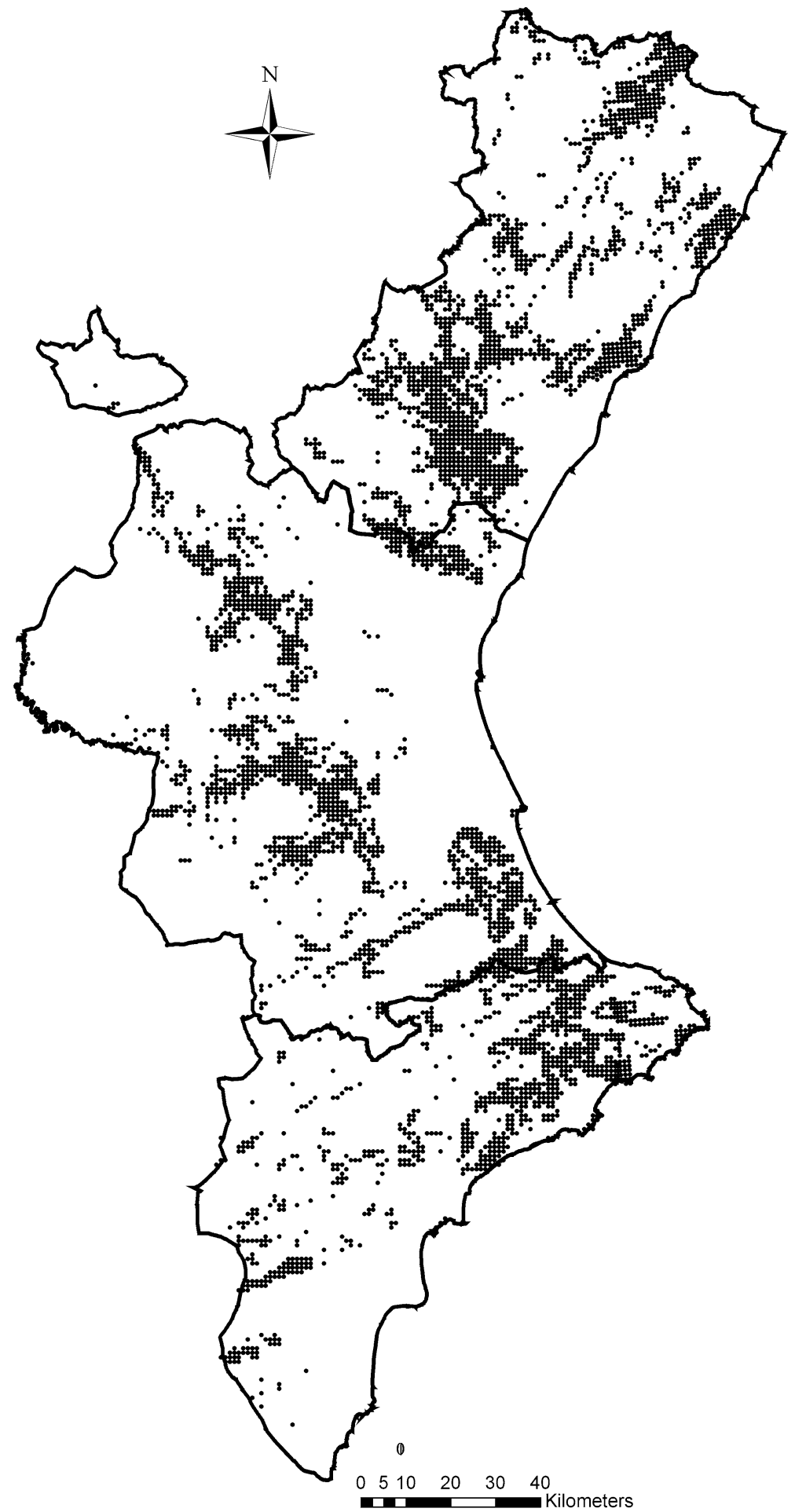

Fig. 5e continued 


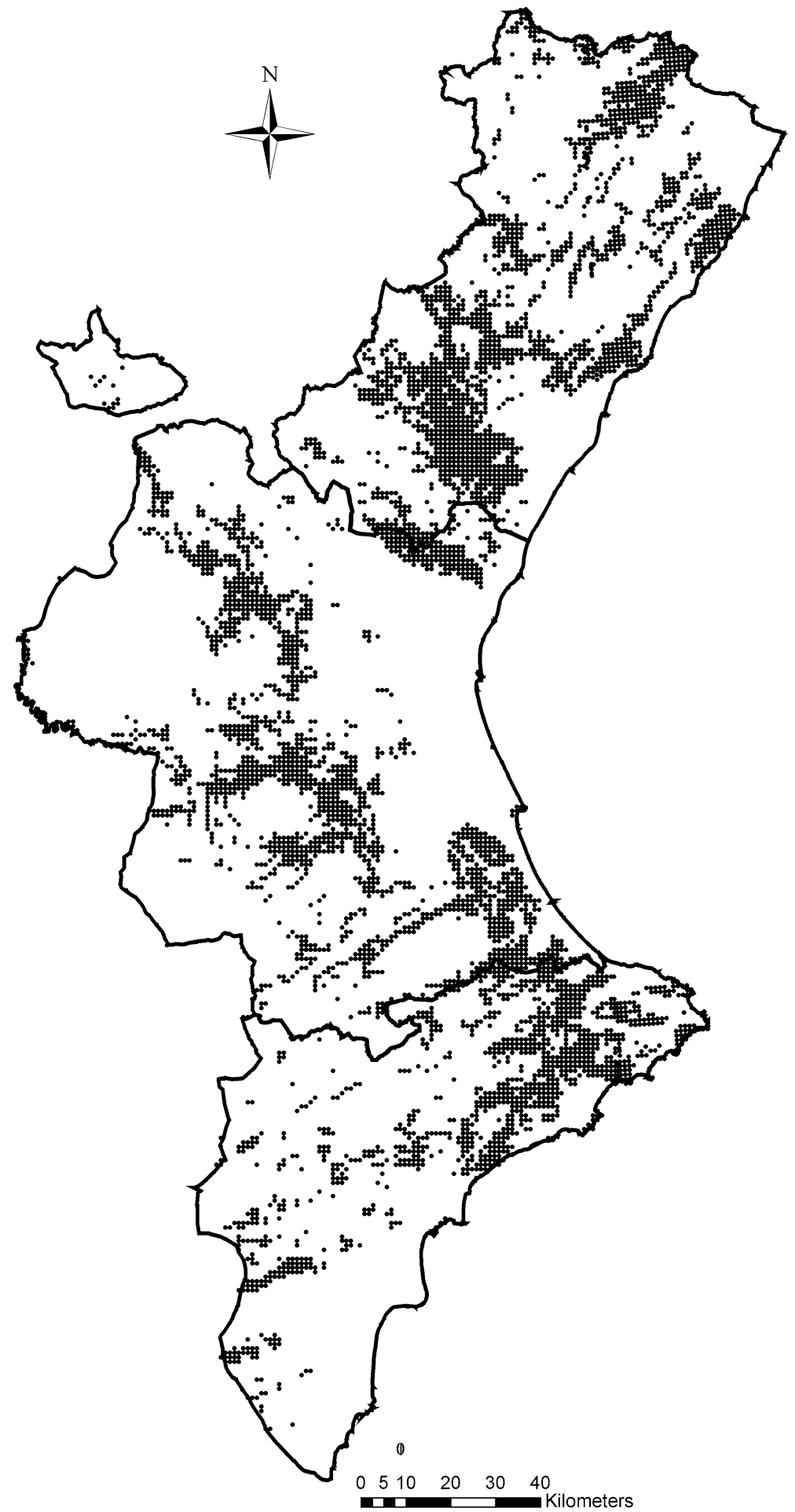

Fig. $5 f$ continued 
wetland areas are clearly delimited ecologically and the IBAs network is suitable for their conservation.

With this approach, we intended to avoid unrealistic results like protecting large scenarios or even the entire area (a trivial result otherwise), trying to optimize the financial budget. Given the trade-off between financial investment and the conservation of biodiversity, our intention was to maximize the surface of potential habitat included in the natural protected network minimizing the surface of the study area that would be necessary to protect, thus avoiding an unnecessary expense. We consider this is a proper solution that relies on objective methods based on biological criteria. Unlike subjective criteria, hitherto usually employed by land managers and some conservation agencies, we base our proposal on a detailed analysis of the habitat requirements of the species obtaining the potential habitat for it. Evidently, we are fully aware that a good network of protected areas should not be based on the requirements of a single species and even of a few species however charismatic they become. Notwithstanding, in a social framework where resources bound for conservation are limited, and considering the urgent need to improve the SPAs network in the Valencian Community, especially in relation to BE conservation, our proposal could be taken into account.

Acknowledgments We would like to thank F. García-López, J.M. Aguilar and J. Verdejo for helping in the fieldwork and their valuable suggestions about raptor biology. We also thank P. Mateache, J. Jimenez and E. Rodríguez of the Conselleria de Territori i Habitatge of the Generalitat Valenciana for their support and GIS assistance. We are grateful to E. Barba for his support and confidence. P. López-López and L. Cadahía are supported by FPU grants of the Spanish Ministerio de Educación y Ciencia (references AP2005-0874 and AP2001-1444, respectively). All the research was compliant with all the laws of Spain where it was conducted. This paper is a part of P. López-López PhD thesis.

\section{References}

Andelman SJ, Fagan WF (2000) Umbrellas and flagships: efficient conservation surrogates or expensive mistakes?. Proc Natl Acad Sci USA 97:5954-5959

Araujo MB (2004) Matching species with reserves-uncertainties from using data at different resolutions. Biol Conserv 118:533-538

Argos (1996) User's manual. CLS/Service Argos, Toulouse

BirdLife (2004a) Birds in Europe: population estimates, trends and conservation status. BirdLife International, Cambridge

BirdLife (2004b) Species factsheet: Hieraaetus fasciatus. BirdLife International, Cambridge

Burley F (1988) Monitoring biological diversity for setting priorities in conservation. In: Wilson E (ed) Biodiversity. National Academy Press, Washington, pp 227-230

Carroll C, Noss RF, Paquet PC (2001) Carnivores as focal species for conservation planning in the Rocky Mountain region. Ecol Appl 11:961-980

De Klerk HM, Fjeldsa J, Blyth S, Burgess ND (2004) Gaps in the protected area network for threatened Afrotropical birds. Biol Conserv 117:529-537

Del Moral JC (2006) El águila perdicera en España. Población en 2005 y método de censo. SEO/BirdLife, Madrid

Dietz RW, Czech B (2005) Conservation deficits for the continental United States: an ecosystem gap analysis. Conserv Biol 19:1478-1487

Encarta-online (2006) "Valencian Community", In Microsoft ${ }^{\odot}$ Encarta $^{\odot}$ Encyclopedia online 2006. 19972006 (C) Microsoft Corporation

ESRI (1999) ArcView GIS 3.2. Environmental Systems Research Institute Inc. 1992-1999, New York

Fjeldsa J, Burgess ND, Blyth S, de Klerk HM (2004) Where are the major gaps in the reserve network for Africa's mammals? Oryx 38:17-25

Groom M, Gary KM, Ronald CC (2006) Principles of conservation biology, 3rd edn. Sinauer Associates, Sunderland 
Guisan A, Zimmermann NE (2000) Predictive habitat distribution models in ecology. Ecol Modell 135:147186

Hosmer DW, Lemeshow S (2000) Applied logistic regression analysis, 2nd edn. Wiley, New York

Keating KA, Cherry S (2004) Use and interpretation of logistic regression in habitat selection studies. J Wildl Manage 68:774-789

Keating KA, Brewster WG, Key CH (1991) Satellite telemetry-performance of animal-tracking systems. J Wildl Manage 55:160-171

Kenward R (2001) A manual for wildlife radio tagging. Academic, San Diego

Kerr JT (1997) Species richness, endemism, and the choice of areas for conservation. Conserv Biol 11:10941100

Kirkpatrick JB (1983) An iterative method for establishing priorities for the selection of nature reserves-an example from Tasmania. Biol Conserv 25:127-134

López-López P, García-Ripollés C, Aguilar JM, García-López F, Verdejo J (2006) Modelling breeding habitat preferences of Bonelli's eagle (Hieraaetus fasciatus) in relation to topography, disturbance, climate and land use at different spatial scales. J Ornithol 147:97-106

López-López P, García-Ripollés C, Urios V (in press a) Population size, breeding performance and territory quality of Bonelli's eagle (Hieraaetus fasciatus) in eastern Iberian Peninsula. Bird Study

López-López P, García-Ripollés C, Soutullo Á, Cadahía L, Urios V (in press b) Identifying potentially nesting habitat for golden eagles (Aquila chrysaetos) applied to Important Bird Areas design. Anim Conserv

Maiorano L, Falcuccia A, Boitani L (2006) Gap analysis of terrestrial vertebrates in Italy: priorities for conservation planning in a human dominated landscape. Biol Conserv 133:455-473

Manly BFJ, McDonald L, Thomas DL, McDonald T, Erickson WP (2002) Resource selection by animals: statistical design and analysis for field studies, 2nd edn. Kluwer Academic Publishers, Dordrecht

Meffe G, Ronald C (1997) Principles of conservation biology. Sinauer Associates, Sunderland

Murphy DD, Noon BR (1992) Integrating scientific methods with habitat conservation planning-reserve design for northern spotted owls. Ecol Appl 2:3-17

Newton I (1979) Population ecology of raptors. T \& AD Poyser, Berkhamstead, UK

Oldfield TEE, Smith RJ, Harrop SR, Leader-Williams N (2004) A gap analysis of terrestrial protected areas in England and its implications for conservation policy. Biol Conserv 120:303-309

Pearce J, Ferrier S (2000) Evaluating the predictive performance of habitat models developed using logistic regression. Ecol Modell 133:225-245

Pressey RL (1994) Ad hoc reservations-forward or backward steps in developing representative reserve systems. Conserv Biol 8:662-668

Primack RB (2000) A primer of conservation biology, 2nd edn. Sinauer, Sunderland

Pullin AS (2004) Conservation biology. Cambridge University Press, Cambridge

Real J (2004) Águila-azor perdicera, Hieraaetus fasciatus. In: Madroño A, González C, Atienza JC (eds) Red book of the birds of Spain. Libro Rojo de las Aves de España. Dirección General para la BiodiversidadSEO/Birdlife, Madrid, pp 154-157

Rodrigues ASL, Tratt R, Wheeler BD, Gaston KJ (1999) The performance of existing networks of conservation areas in representing biodiversity. Proc R Soc Lond Ser B Biol Sci 266:1453-1460

Rodrigues ASL, Andelman SJ, Bakarr MI, Boitani L, Brooks TM, Cowling RM, Fishpool LDC, da Fonseca GAB, Gaston KJ, Hoffmann M, Long JS, Marquet PA, Pilgrim JD, Pressey RL, Schipper J, Sechrest W, Stuart SN, Underhill LG, Waller RW, Watts MEJ, Yan X (2004) Effectiveness of the global protected area network in representing species diversity. Nature 428:640-643

Scott JM, Csuti B, Jacobi JD, Estes JE (1987) Species richness-a geographic approach to protecting future biological diversity. Bioscience 37:782-788

Scott JM, Davis F, Csuti B, Noss R, Butterfield B, Groves C, Anderson H, Caicco S, Derchia F, Edwards TC, Ulliman J, Wright RG (1993) Gap analysis-a geographic approach to protection of biological diversity. Wildl Monogr 121:1-41

Scott JM, Davis FW, McGhie RG, Wright RG, Groves C, Estes J (2001) Nature reserves: do they capture the full range of America's biological diversity? Ecol Appl 11:999-1007

SEO (2006a) Luxembourg judges Spain for insufficient SPA. Luxemburgo juzga a España por insuficientes ZEPA La Garcilla 127:39

SEO (2006b) The Luxembourg Council considers insufficient the Spanish SPA network. El Tribunal de Luxemburgo considera insuficiente la red de ZEPA del estado español. La Garcilla 128:47

Sergio F, Newton I, Marchesi L (2005) Top predators and biodiversity. Nature 436:192-192

Sergio F, Newton I, Marchesi L, Pedrini P (2006) Ecologically justified charisma: preservation of top predators delivers biodiversity conservation. J Appl Ecol 43:1049-1055

Sokal RR, Rohlf FJ (1981) Biometry. Freeman WH and Company, New York 
Soutullo Á, Cadahía L, Urios V, Ferrer M, Negro JJ (in press) Accuracy of lightweight satellite telemetry: a case study in the Iberian Peninsula. J Wildl Manage

StatSoft (2004) STATISTICA (data analysis software system), version 7. StatSoft Incorporated, Tulsa

Steenhof K, Kochert MN (1982) An evaluation of methods used to estimate raptor nesting success. J Wildl Manage 46:885-893

Sutherland WJ, Green RE (2004) Habitat assessment. In: Sutherland WJ, Newton I, Green RE (eds) Bird ecology and conservation. Oxford University Press, Oxford, pp 251-268

Viada C (1998) Áreas Importantes para las Aves en España. Monografía n ${ }^{\circ}$ 5. SEO/BirdLife, Madrid

Yip JY, Corlett RT, Dudgeon D (2004) A fine-scale gap analysis of the existing protected area system in Hong Kong, China. Biodivers Conserv 13:943-957 